\title{
Isolated Laryngeal Coccidioidomycosis - A Case Report and Review of the Literature
}

Antony $\mathrm{N}^{*}$

Texas Tech University Health Sciences Center, El Paso, Texas

${ }^{*}$ Corresponding author: Antony N, Texas Tech University Health Sciences Center, El Paso, Texas, United States, E-mail: nishaalantony@gmail.com

Citation: Antony N (2014) Isolated Laryngeal Coccidioidomycosis - A Case Report and Review of the Literature. J Immunol Infect Dis 2(1): 101. doi: 10.15744/2394-6512.1.201

Received Date: November 04, 2014 Accepted Date: January 02, 2015 Published Date: January 08, 2015

\section{Introduction}

Coccidioidomycosis involving the larynx is a rare occurrence which seems to present with non-specific upper airway symptoms. The diagnosis is made by tissue biopsy and the treatment is usually fluconazole for 6-12 months depending on the clinical presentation. In unusual presentations of laryngeal problems clinicians should consider Coccidioidomycosis, especially in endemic regions.

\section{Case Presentation}

We present a 59-year-old Hispanic female resident of West Texas who presented with symptoms of hoarseness, sore throat, and low-grade fevers for 2-3 months. She had been evaluated by her primary care physician who had treated her with several courses of antibiotics including quinolones, azithromycin, and cephalosporins. Because of the persistence of her symptoms she was sent to an otolaryngologist. On examination her temperature was $98.4 \mathrm{~F}$, blood pressure was $124 / 78 \mathrm{~mm} \mathrm{Hg}$, and pulse $78 \mathrm{bpm}$. Laryngoscope revealed a soft tissue mass along the left side of the airway just above the vocal cords. No cervical lymphadenopathy was noted. The rest of the examination was unremarkable.

A biopsy of the lesion revealed spherules with endospores and accompanying granulomas; fungal cultures were consistent with Coccidiodes immitis. Chest $\mathrm{x}$-ray was unremarkable. Computed tomography (CT) scan of the chest revealed two pulmonary nodules at the superior segment of the left lower lobe. Other relevant labs included hemoglobin and hematocrit of $13.9 \mathrm{~g} / \mathrm{dL}$ and $40.6 \%$ respectively, normal range $11.5-15$ and $34-44$. White blood count was 11,000 per $\mu \mathrm{L}$ (4-10.5) with 58\% neutrophils, 31\% lymphocytes, $8 \%$ monocytes, $2 \%$ eosinophils, and $1 \%$ basophils. The $C$. immitis complement fixation titer (CFT) was negative at $<1: 1$ and enzyme immunoassay (EIA) was unavailable. The patient was placed on fluconazole $400 \mathrm{mg}$ per day for 6 months. Serial follow-ups revealed a decreasing size of the laryngeal mass with complete resolution of the lesion by the end of 3 months and repeat a chest $\mathrm{x}$-ray demonstrated some resolution in the size of the lung nodules. Repeat serum Coccidioidomycosis CFT level remained negative.

\section{Discussion}

Coccidioidomycosis spp. is a dimorphic fungus endemic to the southwestern United States and Northern Mexico [1]. Infection occurs through inhalation of the Coccidioidomycosis arthroconidium from the soil. The areas with the highest endemic sources of infection are in California and Arizona which together make up more than $50 \%$ of all cases [2]. The incidences in high-risk locations have risen from 5.3 cases per 100,000 in 1998 to 42.6 per 100,000 cases in 2011 [3]. This rise in reported cases has been in part hypothesized to the increased sensitivity of Coccidioidomycosis serological tests and industrialization into endemic areas [3,4]. The most common presentation of Coccidioidomycosis includes symptoms of chronic fatigue, malaise, and productive cough. Episodes of occasional of arthralgias are common with a primary pulmonary source as well [5]. The risk factors associated with severe disseminated infection are immunosuppression such as, AIDS, solid organ transplant recipients, lymphomas, or prolonged steroid use [6]. While the vast majority of Coccidioidomycosis infections have a primary pulmonary source, primary Coccidioidomycosis of the larynx is a very rare and unusual presentation.

A review of the literature was done using Medline and PubMed and was simplified into a table (Table 1). The following characteristics seemed consistent with patients with laryngeal Coccidioidomycosis. First, the most common complaint appeared to be vocal changes, primarily hoarseness of the voice in $50 \%$ of cases. Other presenting symptoms were cough, malaise, and a nonspecific flu-like presentation. Secondly, $50 \%$ of the patients demonstrated evidence of possible pulmonary involvement with chest imaging, however only $23 \%$ of patients underwent bronchoscopies or pulmonary biopsies. In a majority of cases, the diagnosis was confirmed with a biopsy of the larynx or sputum cultures. And thirdly, in $58 \%$ of cases the CFTs were equal or greater than 1:16. Any positive CFT is considered clinically relevant; IgG will diminish over a period of 6 months after treatment. It is for this reason that it is used as a marker of successful therapy along with clinical resolution of the initial symptoms. In addition, PCR for Coccidioidomycosis spp has been developed which has shown very high sensitivity and specificity in infected patients [7]. As well, 
use of enzyme immunoassay (EIA) for patients infected with Coccidioidomycosis can assist with a definite diagnosis in presence of an inconclusive or inconsistent CFT [8]. Sensitivity for patients with symptomatic infections is very high, however in immunocompromised or asymptotic patients results should be interpreted with caution [8].

\begin{tabular}{|c|c|c|c|c|c|c|c|c|}
\hline Author & Year & $\begin{array}{l}\text { Age/ } \\
\text { Sex }\end{array}$ & Presentation & Diagnosis & $\begin{array}{l}\text { Pulmonary } \\
\text { Cocci }\end{array}$ & Serology & Therapy & Outcome \\
\hline $\begin{array}{l}\text { Allen } \\
\text { et al. }\end{array}$ & 2011 & $52 / \mathrm{F}$ & $\begin{array}{l}1 \text { year history of } \\
\text { dysphonia and cough } \\
\text { with prior history of } \\
\text { treated pulmonary } \\
\text { cocciodioidomycosis }\end{array}$ & $\begin{array}{c}\text { Videolaryngoscopy } \\
\text { postive for } \\
\text { erytema and } \\
\text { pseudomembranous } \\
\text { exudate over } \\
\text { epiglottis and } \\
\text { periform fosssa. } \\
\text { Chest CT } \\
\text { demonstrated large } \\
\text { peumoceles and } \\
\text { lung damge. Biopsy } \\
\text { of vocal cords and } \\
\text { sputum cultures grew } \\
\text { C. immitis. }\end{array}$ & No & $\begin{array}{l}\text { Comple- } \\
\text { ment } \\
\text { fixation titer } \\
\text { (CFT) was } \\
1: 32\end{array}$ & Fluconazole & $\begin{array}{c}\text { After } 6 \text { weeks of } \\
\text { antifungal therapy, } \\
\text { largyngoscopy noted } \\
\text { complete resolution } \\
\text { of infection. }\end{array}$ \\
\hline $\begin{array}{l}\text { Patel et } \\
\text { al. }\end{array}$ & 2009 & $28 / \mathrm{M}$ & $\begin{array}{l}1 \text { week history of } \\
\text { sore throat, hoarse- } \\
\text { ness, dry cough, and } \\
\text { dysphagia }\end{array}$ & $\begin{array}{l}\text { Contrast computed } \\
\text { tomography } \\
\text { scan of neck and } \\
\text { chest positive for } \\
\text { abscess on false } \\
\text { vocal cord with } \\
\text { lymphadenopathy } \\
\text { and pulmonary } \\
\text { nodules; culture } \\
\text { positive for } C \text {. } \\
\text { immitis. }\end{array}$ & Yes & $\begin{array}{l}\text { Undetect- } \\
\text { able IgG \& } \\
\text { IgM }\end{array}$ & I\&D; oral fluconazole & Clinically improved \\
\hline $\begin{array}{l}\text { Crum } \\
\text { et al. }\end{array}$ & 2004 & $47 / \mathrm{M}$ & $\begin{array}{l}\text { Hoarseness, neck } \\
\text { adenopathy and } \\
\text { increasing CF titer, } \\
\text { history of pulmonary } \\
\text { coccidioidomycosis }\end{array}$ & $\begin{array}{l}\text { FNA of neck LN } \\
\text { was negative, } \\
\text { laryngoscopy noted } \\
3 \text { nodules on vocal } \\
\text { cords which yielded a } \\
\text { positive diagnosis }\end{array}$ & No & $\begin{array}{l}\text { CFT } \\
\text { was 1:8, } \\
\text { increased } \\
\text { from 1:2 }\end{array}$ & $\begin{array}{l}\text { Fluconazole 600mg QD } \\
\text { for } 2 \text { months }\end{array}$ & $\begin{array}{l}\text { Adenopathy and } \\
\text { hoarseness resolved } \\
\text { over } 2 \text { months. No } \\
\text { relapses over } 11 \\
\text { month follow-up } \\
\text { peroid. }\end{array}$ \\
\hline $\begin{array}{l}\text { Rosen } \\
\text { et al. }\end{array}$ & 2001 & $14 ? \mathrm{M}$ & $\begin{array}{l}3 \text { week history of } \\
\text { worsening hoarseness } \\
\text { and dyspnea; history } \\
\text { of disseminated } \\
\text { coccio as a child }\end{array}$ & $\begin{array}{l}\text { Chest X-ray noted } \\
\text { calcified granulomas } \\
\text { consistent with } \\
\text { previously treated } \\
\text { pulmonary } \\
\text { coccidioidomycosis. } \\
\text { Laryngoscopy with } \\
\text { biopsy grew C. } \\
\text { immitis. }\end{array}$ & No & $\begin{array}{l}\text { IgG was } \\
\text { positive, } \\
\text { CFT was } \\
1: 16\end{array}$ & $\begin{array}{l}\text { IV fluconazole for } 3 \\
\text { days, switched to PO } \\
\text { 200mg Q6hr }\end{array}$ & Unknown \\
\hline $\begin{array}{l}\text { Boyle } \\
\text { et al. }\end{array}$ & 1991 & $40 / \mathrm{F}$ & $\begin{array}{l}6 \text { week history of } \\
\text { moderate hoarseness, } \\
\text { lymphadenopathy of } \\
\text { the rt side of the neck, } \\
\text { fever, night sweats, } \\
\text { moderate dry cough, } \\
\text { and fatigue }\end{array}$ & $\begin{array}{l}\text { Contrast computed } \\
\text { tomography scan } \\
\text { of neck positive } \\
\text { for supraglottic } \\
\text { edema and near } \\
\text { total compromise } \\
\text { of the airway as } \\
\text { well as bilateral } \\
\text { lymphadenopathy } \\
\text { and a nodule on } \\
\text { right perijugular } \\
\text { lymph node; biopsy } \\
\text { and histological } \\
\text { examination positive } \\
\text { for caseating } \\
\text { granulomas and } \\
\text { multinucleated giant } \\
\text { cells, double walled } \\
\text { spherules with } \\
\text { endospores indicated } \\
\text { C. immitis. }\end{array}$ & Yes & $\begin{array}{l}\text { IgM; CFT } \\
\text { was } 1: 32\end{array}$ & Fluconazole & Clinically improved \\
\hline
\end{tabular}




\begin{tabular}{|c|c|c|c|c|c|c|c|c|}
\hline Author & Year & $\begin{array}{l}\text { Age/ } \\
\text { Sex }\end{array}$ & Presentation & Diagnosis & $\begin{array}{c}\text { Pulmonary } \\
\text { Cocci }\end{array}$ & Serology & Therapy & Outcome \\
\hline $\begin{array}{l}\text { Hajare } \\
\text { et al. }\end{array}$ & 1989 & $\begin{array}{c}31 \\
\mathrm{mo} / \mathrm{M}\end{array}$ & $\begin{array}{l}2 \text { day history of } \\
\text { respiratory distress } \\
\text { and stridor, history } \\
\text { of steroid-dependent } \\
\text { nephrotic syndrome }\end{array}$ & $\begin{array}{l}\text { Chest X-ray was } \\
\text { unremarkable. } \\
\text { Laryngoscope } \\
\text { revealed epiglottic } \\
\text { and subglottic } \\
\text { edema. Tracheal } \\
\text { aspirate grew C. } \\
\text { immitis. }\end{array}$ & No & $\begin{array}{c}\text { CFT was } \\
1: 32\end{array}$ & $\begin{array}{l}\text { Amphotericin B for } \\
4 \text { weeks however d/c } \\
\text { due to worsening renal } \\
\text { function. Switched to } \\
\text { fluconazole PO } 6.6 \mathrm{mg} / \\
\mathrm{kg} / \text { day for } 1 \text { year }\end{array}$ & $\begin{array}{l}\text { Compliment fixation } \\
\text { was negative } 6 \\
\text { months after hospital } \\
\text { discharge }\end{array}$ \\
\hline Dudley & 1987 & $21 \mathrm{~F}$ & $\begin{array}{l}3 \text { month history of } \\
\text { gradually increasing } \\
\text { neck mass and reports } \\
\text { of not feeling "up to } \\
\text { par" }\end{array}$ & $\begin{array}{l}\text { Mass excised and } \\
\text { histologic evidence } \\
\text { of caseating } \\
\text { granulomas. }\end{array}$ & No & $\begin{array}{c}\text { CFT was } \\
1: 2\end{array}$ & Excised; no antbx & $\begin{array}{l}3 \text { year follow up } \\
\text { showed no evidence } \\
\text { of infection }\end{array}$ \\
\hline Dudley & 1987 & $13 / \mathrm{F}$ & $\begin{array}{l}\text { Neck mass and } \\
\text { lethargy; } 1 \text { year later } \\
\text { neck nodes developed } \\
\text { again, bilaterally }\end{array}$ & $\begin{array}{l}\text { Biopsy/ histology } \\
\text { confirmation; Biopsy } \\
\text { showed caseating } \\
\text { granulomas with } \\
\text { endospore-packed } \\
\text { spherules }\end{array}$ & No & $\begin{array}{l}\text { CFT 1:2; } \\
\text { CFT 1:32 }\end{array}$ & $\begin{array}{l}\text { Ketoconazole } 6 \mathrm{mo} \text {; } \\
\text { ketoconazole }(600 \mathrm{mg}) \\
\text { daily for } 3 \mathrm{mo} .\end{array}$ & $\begin{array}{l}\text { Cervical adenopathy } \\
\text { disappeared; } \\
\text { Cervical adenopathy } \\
\text { disappeared with no } \\
\text { signs of return over } 3 \\
\text { year follow up }\end{array}$ \\
\hline $\begin{array}{l}\text { Benitz } \\
\text { et al. }\end{array}$ & 1983 & $5 / \mathrm{M}$ & $\begin{array}{l}5 \text { week history of } \\
\text { right-sided pleuritic } \\
\text { chest pain, cough, } \\
\text { fever, occasional night } \\
\text { sweats; increasing } \\
\text { stridor and intercostal } \\
\text { retractions. }\end{array}$ & $\begin{array}{l}\text { Chest X-ray } \\
\text { showed infiltrates } \\
\text { in the middle and } \\
\text { lower lobes of the } \\
\text { right lung as well } \\
\text { as mediastinal } \\
\text { lymphadenopathy } \\
\text { on the right. } \\
\text { Coccidiodin } \\
\text { skin test positive. } \\
\text { Laryngoscopy } \\
\text { and biopsy } \\
\text { was performed } \\
\text { and histologic } \\
\text { examination showed } \\
\text { granulomatous } \\
\text { lympadenitis and } \\
\text { spherules consistent } \\
\text { with C. immitis. }\end{array}$ & No & $\begin{array}{c}\text { CFT } 1: 8 \\
\text { initially, but } \\
\text { up to } 1: 32\end{array}$ & $\begin{array}{l}\text { Amphotericin B for } 10 \\
\text { wk (total dose of } 60 \mathrm{mg} / \\
\mathrm{kg} \text { ) }\end{array}$ & $\begin{array}{l}\text { After } 14 \text { month } \\
\text { there was no further } \\
\text { recurrence of } \\
\text { respiratory distress or } \\
\text { stridor }\end{array}$ \\
\hline $\begin{array}{l}\text { Gard- } \\
\text { ner et } \\
\text { al. }\end{array}$ & 1980 & $1 / \mathrm{M}$ & $\begin{array}{l}3 \text { month history of } \\
\text { rhinitis, stridor, and } \\
\text { cough. Also noted } \\
\text { were lethargy and } \\
\text { dysphonia. }\end{array}$ & $\begin{array}{l}\text { Bronchoscopy/ } \\
\text { biopsy; sample } \\
\text { obtained showed } \\
\text { histologic evidence } \\
\text { of granulomas and } \\
\text { spherules suggestive } \\
\text { of endospores } \\
\text { consistent with } \\
\text { C. immitis. The } \\
\text { pathogen was also } \\
\text { isolated from the } \\
\text { sample; a skin C. } \\
\text { immitis skin test } \\
\text { showed } 5 \text { mm of } \\
\text { induration and } \\
\text { erythema. }\end{array}$ & Yes & CFT was 1:8 & $\begin{array}{l}\text { Amphotericin B } \\
\text { (IV) for } 4 \mathrm{mo} \text { (total } \\
\text { dose } 65 \mathrm{mg} / \mathrm{kg} \text { ) and } \\
\text { tracheostomy }\end{array}$ & $\begin{array}{l}\text { Although CFT } \\
\text { remined unchanged } \\
\text { and skin test positive, } \\
\text { no symptoms or } \\
\text { growth recorded at } 5 \\
\text { month follow up }\end{array}$ \\
\hline $\begin{array}{l}\text { Ward } \\
\text { et al. }\end{array}$ & 1977 & $\begin{array}{c}4.5 \\
\mathrm{mo} / \mathrm{M}\end{array}$ & $\begin{array}{l}3 \text { month history of } \\
\text { upper respiratory } \\
\text { tract infection } \\
\text { associated with } \\
\text { wheezes and cough; } \\
\text { subglottic stenosis } \\
\text { with granular lessions }\end{array}$ & $\begin{array}{l}\text { Laryngoscope and } \\
\text { biopsy were taken; } \\
\text { upon histopathologic } \\
\text { examination fibrous } \\
\text { stroma and sphrules } \\
\text { consistent with } C \text {. } \\
\text { immitis were found. }\end{array}$ & No & $\begin{array}{l}\text { CFT ranged } \\
\text { from } 1: 32 \text { to } \\
1: 128\end{array}$ & $\begin{array}{l}\text { Amphotericin B until } \\
\text { CFT returned to 1:32 } \\
\text { (total dose } 271 \mathrm{mg} \text { ) }\end{array}$ & $\begin{array}{l}\text { At } 6 \text { month post- } \\
\text { treatment follow up, } \\
\text { patient had no signs } \\
\text { of infection and } \\
\text { healthy }\end{array}$ \\
\hline
\end{tabular}




\begin{tabular}{|c|c|c|c|c|c|c|c|c|}
\hline Author & Year & $\begin{array}{l}\text { Age/ } \\
\text { Sex }\end{array}$ & Presentation & Diagnosis & $\begin{array}{c}\text { Pulmonary } \\
\text { Cocci }\end{array}$ & Serology & Therapy & Outcome \\
\hline Platt & 1977 & $45 / \mathrm{M}$ & $\begin{array}{l}\text { Hoarseness for } 1 \text { year } \\
\text { with associated fever, } \\
\text { maliase, hemoptysis } \\
\text { and weight loss; } \\
\text { history of pulmonary } \\
\text { coccidioidomycosis } \\
\text { s/p lobectomy }\end{array}$ & $\begin{array}{l}\text { Chest X-ray showed } \\
\text { extenstive bilateral } \\
\text { infiltration with } \\
\text { caviation. C. immitus } \\
\text { was isolated in the } \\
\text { sputum cultures. }\end{array}$ & No & $\begin{array}{c}\text { CFT was } \\
1: 28-1: 256\end{array}$ & $\begin{array}{l}\text { Amphotericin B for } \\
2 \text { year intermittently, } \\
\text { however sputum was } \\
\text { still positive. Switched } \\
\text { to miconazole nitrate } \\
\text { for } 10 \text { weeks for } \\
\text { resolution. }\end{array}$ & $\begin{array}{l}\text { Acute infection was } \\
\text { resolved however } \\
\text { bone marrow aspirate } \\
\text { to assess anemia } \\
\text { noted spherules of } C \text {. } \\
\text { immitus. }\end{array}$ \\
\hline $\begin{array}{l}\text { Singh } \\
\text { et al. }\end{array}$ & 1956 & $34 / \mathrm{M}$ & $\begin{array}{l}\text { Produtive cough for } 3 \\
\text { month with dyspha- } \\
\text { gia and hoarseness for } \\
1 \text { month }\end{array}$ & $\begin{array}{l}\text { Tracheostomy with } \\
\text { biopsy of tracheal } \\
\text { cartilage grew } C \text {. } \\
\text { immitus. Biopsies } \\
\text { from cutaneous } \\
\text { lesions also grew the } \\
\text { fungus. }\end{array}$ & No & $\begin{array}{l}\text { CFT was } \\
\text { positive }\end{array}$ & $\begin{array}{l}\text { Dihydroxystilbamidine } \\
\text { (IV) Q4hrs, total of } 20 \\
\text { doses. }\end{array}$ & $\begin{array}{l}3 \text { month after } \\
\text { therapy, cutaneous } \\
\text { lesions were healing } \\
\text { and patient no } \\
\text { longer required } \\
\text { tracheostomy }\end{array}$ \\
\hline
\end{tabular}

Table 1: Review Literature of Coccidioidomycosis

The current treatment of laryngeal Coccidioidomycosis is amphotericin B or fluconazole, however the drug of choice is fluconazole [1,9-19]. To date, there have been no cases of laryngeal Coccidioidomycosis being treated with the newer azoles such as voriconazole or posaconazole. Relapse rates in isolated laryngeal infections are not known due to the scarcity of documented cases.

In this case, the usual features included multiple repeat negative CFT's, no definite evidence of pulmonary disease, and an isolated infection in an otherwise healthy female. At this point it would be difficult to speculate as to whether she would have had a positive EIA in the presence of a localized infection. However, given the laboratory and clinical data available, it would indicate the primary source of the patient's Coccidioidomycosis infection was limited only to her larynx. Due to her lack of pulmonary symptoms and negative CFT, a bronchoalveolar lavage was unnecessary and would add unneeded risks to the patient. There have been many proposed hypotheses of isolated laryngeal involvement however no proven theory has emerged as yet [20]. The most likely etiology of laryngeal involvement is from hematogenous spread of a primary pulmonary focus or dissemination from a high fungal burden in the host [20]. However, the etiology of our patient's laryngeal Coccidioidomycosis is not clear.

Due to the sporadicity of cases of laryngeal involvement of Coccidioidomycosis, morbidity and mortality is difficult to determine. With ease and mobility of travel it is very feasible for patients who live outside the expected area of infectivity to develop this illness. While cases of isolated laryngeal C. immitis are exceedingly rare, one should consider uncommon fungal etiologies like Coccidioidomycosis in patients with difficult to treat upper respiratory tract or pneumonia-like symptoms.

In summary, laryngeal Coccidioidomycosis is an unusual presentation of a common illness endemic to the southwestern United States. The diagnosis is made on the biopsy of the larynx and treatment is with fluconazole for 6-12 months.

\section{Acknowledgement}

Dr. Suresh J. Antony for his input and assistance in developing this manuscript.

\section{References}

1. Boyle JO, Coulthard SW, Mandel RM (1991) Laryngeal involvement in disseminated coccidioidomycosis. Arc Otolaryngol Head Neck Surg 117: 433-8.

2. Pappagianis D (1980) Epidemiology of coccidioidomycosis. Coccidioidomycosis, Springer US, 63-85.

3. Centers for Disease Control and Prevention (CDC) (2013) Increase in reported coccidioidomycosis--United States, 1998-2011. MMWR Morb mortal wkly rep 62: 217-21.

4. Hector RF, Rutherford GW, Tsang CA, Erhart LM, McCotter O, et al. (2011) The public health impact of coccidioidomycosis in Arizona and California. Int J Environ Res Public Health 8: 1150-73.

5. Smith CE (1940) Epidemiology of Acute Coccidioidomycosis with Erythema Nodosum. Am J Public Health Nations Health 30: 600-11.

6. Antony SJ, Dummer SJ, McNeil KK, Salas I (2005) Coccidioidomycosis in renal transplant recipients. Infect Dis Clin Prac13: 250-4.

7. Gago S, Buitrago MJ, Clemons KV, Cuenca-Estrella M, Mirels LF, et al. (2014) Development and validation of a quantitative real-time PCR assay for the early diagnosis of coccidioidomycosis. Diagn microbiol Infect Dis 79: 214-21.

8. Blair JE, Mendoza N, Force S, Chang YH, Grys TE (2013) Clinical specificity of the enzyme immunoassay test for coccidioidomycosis varies according to the reason for its performance. Clin Vaccine Immunol 20: 95-8.

9. Patel S, Snyder L (2009) A Sore Throat in the Southwest. Am J Med 122: 233-5.

10. Allen JE, Belafsky PC (2011) Laryngeal coccidioidomycosis with vocal fold paralysis. Ear, nose, throat j 90: E1-5.

11. Crum NF, Lederman ED, Stafford CM, Parrish JS, Wallace MR (2004) Coccidioidomycosis: a descriptive survey of a reemerging disease. Clinical characteristics and current controversies. Medicine 83: 149-75.

12. Rosen EJ, Newlands SD, Patel J, Kalia A, Friendman, NR (2001) Reactivated laryngeal coccidioidomycosis. Otolaryngol Head Neck Surg 125: 120-1.

13. Hajare S, Rakusan TA, Kalia A, Gibson FB, Strunk CL (1989) Laryngeal coccidioidomycosis causing airway obstruction. Pediatr Infect Dis J 8: 54-6.

14. Dudley JE (1987) Coccidioidomycosis and neck mass 'single lesion’ disseminated disease. Arc Otolaryngo Head Neck Surg 113: 553-5.

15. Benitz WE, Bradley JS, Fee WE, Loomis JC (1983) Upper airway obstruction due to laryngeal coccidioidomycosis in a 5-year-old child. Am J Otolaryngo 4: $367-70$. 
16. Gardner S, Seilheimer D, Catlin F, Anderson DC, Hernried L (1980) Supglottic coccidioidomycosis presenting with persistent stridor. Pediatrics 66: 623-5. 17. Ward PH, Berci G, Morledge D, Schwartz H (1976) Coccidioidomycosis of the larynx in infants and adults. Ann Otol Rhinol Laryngol 86: 655-60.

18. Galgiani JN, Ampel NM, Blair JE, Catanzaro A, Johnson RH, et al. (2005) Coccidioidomycosis. Clin Infect Dis 41: $1217-23$.

19. Singh H, Yast CJ, Gladney JH (1956) Coccidioidomycosis with endolaryngeal involvement. AMA Arch Otolaryngol 63: 244-7.

20. Platt MA (1977) Laryngeal coccidioidomycosis. JAMA 237: 1234-5.

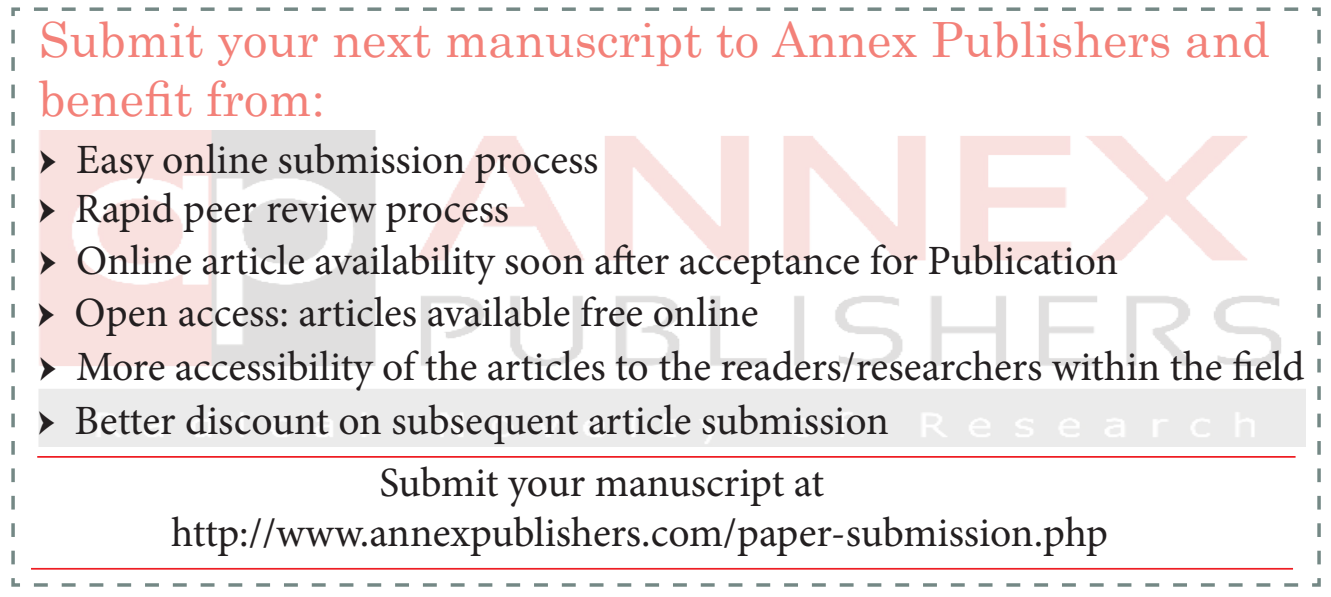

